Crime, Histoire \& Sociétés / Crime, History \& Societies

Vol. 3, n² | 1999

Varia

\title{
Political policing
}

\section{Simon Kitson}

\section{(2) OpenEdition}

\section{Journals}

Electronic version

URL: https://journals.openedition.org/chs/893

DOI: $10.4000 /$ chs. 893

ISSN: 1663-4837

\section{Publisher}

Librairie Droz

\section{Printed version}

Date of publication: 1 June 1999

Number of pages: 95-102

ISBN: 2-600-00398-3

ISSN: $1422-0857$

Electronic reference

Simon Kitson, "Political policing", Crime, Histoire \& Sociétés / Crime, History \& Societies [Online], Vol. 3, n² | 1999, Online since 03 April 2009, connection on 22 March 2022. URL: http:// journals.openedition.org/chs/893; DOl: https://doi.org/10.4000/chs.893

(c) Droz 


\section{Political policing}

Jean-Marc Berlière, Denis Peschanski, (Eds.), Pouvoirs et polices au XX $X^{e}$ siècle, Bruxelles, Complexe, 1997, 324 p., ISBN 2870276826 1.

Mark Mazower, (Ed.), The Policing of Politics in the Twentieth Century, Oxford, Berghahn,1997, 262 p., ISBN 15781 8791².

\section{Martha Huggins, Political policing: The United States and Latin America, Durham (NC), Duke University Press, 1998, 248 p., ISBN 0822321726.}

Three high quality texts have recently made their appearance which further both our knowledge of the development of political policing in the 20th century and allow a comparative analysis of this phenomenon. The Huggins book is a fascinating account of the role played by the United States in training and manipulating Latin American police forces and by extension US responsibility in the excesses of these forces. Although the text begins rather slowly and the early chapters tend towards repetition, the patience of those who read the publication in its entirety is definitely rewarded. The Mazower and Berlière/Peschanski collections are also

1 Contributions: Berlière, J.-M., Peschanski, D., Histoires de polices au miroir de laz comparaison; Lévy, R., Qui détient le pouvoir de police?; Dunnage, J., La police et le fascisme italien; Lessman, P., 'Au poste perdu': la police en Prusse, 1930-1933; Gellately, R., L'émergence de la 'Polizeijustiz' dans l'Allemagne nazie; Tipton, E., De la 'police du peuple' à la 'police de l'Empereur': la police japonaise dans les années trente; S., Leonor, Police judiciaire contre police politique au Portugal pendant la Première République et la dictature de Salazar; Altman, I., Les organes de sécurité pendant les dernières années de Staline: la guerre au Juif; Tartakowsky, D., Les polices en pays occupés ou sous tutelle; Berlière, J.-M., Peschanski,D., Polices et policiers parisiens face à la lutte armée (1941-1944); Fijnaut, C., La police belge avant, durant et après l'occupation; Delpuech, T., La police et la justice sous tutelle en Bulgarie: les héritages ottoman et soviétique; Bessl, R., Les limites d'une dictature. Police et société en Allemagne de l'Est, 1945-1953; Reinke, H., 'La police doit être un corps clair comme du cristal': l'épuration de la police en Allemagne de l'Ouest et de l'Est après 1945; Jeffrey, K., 'RUC $=S S$ '. Á propos du Royal Ulster Constabulary considéré comme une force d'occupation, (1922-1969); Theoharis, A., Le contrôle du FBI par l'exécutif et le congrès: réformes et abus; Monkkonen, E., La police aux États-Unis depuis la Seconde Guerre mondiale.

2 Contributions: Emsley, C., Introduction: Political police and the European Nation-State in the Nineteenth Century; Berlière,J.-M., A Republican political police? Political policing in France under the Third Republic, 1875-1940; Dunnage, J., Continuity in policing politics in Italy, 1920-1960; Reinke, H., Policing politics in Germany from Weimar to the Stasi; Fijnaut, C., The International Criminal Police Commission and the fight against communism, 1923-1945; Mazower, M., Policing the AntiCommunist State in Greece, 1922-1974; Jeffrey, K., Police and government in Northern Ireland, 1922-1969; Killingray, D., Securing the British Empire: policing and colonial order, 1920-1960; Theoharis, A., Political policing in the United States: the evolution of the FBI, 1917-1956; Tipton, E., The Tokko and political policing in Japan, 1911-1945; Mazower, M., Conclusion : the policing of politics in historical perspective. 
hugely valuable contributions to the debate on policing. They cover fairly similar ground and include some of the same authors. 'The policing of politics' gives comparatively more space to the role of political police in democracies, whilst the centre of focus in 'Pouvoirs et police' revolves more around the war years and questions of political policing under totalitarian regimes. Also, whilst the Mazower collection is mainly concerned with the role of the political police, the Berlière and Peschanski text is much looser in its association of police and politics, seeing the police both as an actor of political policing and its victim- the dreaded word 'purge' ('épuration') occurs more frequently in the French text. The editors of these two highly readable and insightful collections are to be praised for gathering together a large proportion of the world's leading experts on policing matters.

One severe regret must, however, be expressed at the outset regarding the two collective works. In both cases attention is almost entirely limited to policing the developed world (although Killingray, in Mazower, deals with policy in British colonies). This remark is not intended as a specific attack on the editors, who have done no more in this respect than firmly entrench themselves in a western tradition. It is not made clear whether restricting the range of texts in this way was the result of a deliberate choice to help assure the coherence of the texts by comparing like with like or simply due to practical factors, for example the generally limited interaction of specialists of the developed and developing worlds or possibly even a reflection of the embryonic nature of studies of the policing of Third World. This comment takes nothing away from the quality or importance of these collections as they stand but it is obvious that many of the questions raised would have interesting parallels in for example many African states- it is therefore all the more interesting to place them along side the Huggins book to allow comparative analysis to be extended.

The first element that should be noted is that although political policing is almost a symbol of the Twentieth Century it did not originate in it. This is an aspect which is examined with his usual clarity and insight by Clive Emsley (in Mazower). In the 18 th and 19th centuries states developed an ever growing thirst for knowledge of their citizens resulting in an increasing use of political police both to enforce codes of behaviour and to limit internal opposition. Behind this evolution lay both political and social changes. The French Revolution fostered a fear amongst the leaders of other countries that similar uprisings could spread to their territories. Paradoxically the initial revolutionaries, the French, were particularly keen to tighten up political police because having participated in such an uprising they were fully aware of the potential of revolution. Improved communications compared with earlier periods also meant that it was easier for isolated rumblings to spiral into a mass movement.

Once political police forces had developed regimes were very reluctant to disarm themselves in this domain. This explains why, contrary to the affirmations of certain police officials, political policing became prevalent even in democracies. Many of the authors insist upon the continuities of political policing between democracies and dictatorships whether these be in the form of structural continuities, similarity of targets or certain general characteristics and methods.

New regimes often regard a police force inherited from a predecessor of differing ideological persuasion with great mistrust. When they assume control they have the choice of establishing a new institution, reforming the structures of the existing one or changing its personnel. Abolishing existing structures was rare in the case of passage from democracy to dictatorship and structural continuities of the sort noted by Sà with regard to the introduction of dictatorship in Portugal were not untypical (Sà 
in Berlière \& Peschanski). It was far more common if a new police force was to be established (particularly one built around its ties with the single party of a totalitarian regime) for it to co-exist with the pre-established security forces. This attempted to make use of the age-old theory of divide and rule, hoping that new and old structures would mutually spur each other into action through rivalry with the infusion of a political agenda from the new force and professional expertise from the old. Reforming inherited structures could likewise serve as a means of differentiating the new regime from the old as well as a way of trying to assure the control of the institution. In France during the Second World War the 1941 police reform was introduced instead of carrying out a mass purge of the personnel (Berlière \& Peschanski in Berlière \& Peschanski). Although this purge of personnel was felt desirable in this case because it was clear that the existing force was not politically favourable, it remained limited. This resulted partly from the hope that police professionalism would limit the effect of this political divergence by encouraging a passive obedience, but much more importantly from the realisation that the absence of more than one and a half million men as prisoners of war made it impossible to envisage the recruitment of anyone to replace purged elements in a police force which was already failing to meet its recruitment targets. When passing from dictatorships to democracies changes were generally greater. For instance police structures established by the Nazis or their sidekicks tended to be purely and simply abolished at the liberation of these countries except in cases where the reforms were based on pre-war plans. France provides a perfect example of both these processes with the abolition of Vichy inspired parallel polices or specialised branches of the regular police but the maintenance of the 1941 overhaul of the police structure which was based on projects Vichy had inherited from the Republican regime. Purges were also initially greater in this case than in the passage from democracy to dictatorship: it was felt to be easier for a dictatorship to make use of 'democratic' police officers who had been trained to obey regimes of different political convictions than it was to use police officers who had been recruited at a time where the police were the most politically marked. Ultimately however, after initial zeal in the removing of suspect elements, purges of personnel following the defeat of the Axis were limited by the onset of the cold war and the wish to draw on their anti-communist zeal (Mazower; Dunnage in Mazower). In any event, nowhere were purges of police personnel more complete than in the passage from one dictatorship to another in the newly founded East Germany where police officers were drawn almost exclusively from those who had not served in the institution during the Nazi regime (Bessel; Reinke in Berlière \& Peschanski). To mark the passage from one type of regime to another great attention was paid to the presentation of the institution- its physical appearance as well as its name (Tipton in Mazower). During the period 1926 to 1974 , the Portuguese political police changed name over ten times, compared with just once for the criminal police (Sà in Berlière \& Peschanski). Calling a force the 'people's police' assured superficial credibility at least until its mission became too obviously political (Bessel in Berlière \& Peschanski).

In democracy the police is presented not as the prop of an autocratic dictator but rather as the defender of public freedom. Aware that their regime depends partly on public support leaders try to at least give the appearance that their police are defending public liberties, even if this process hides certain ambiguities. The police claim to be serving public interest needs to be placed alongside the fact that even in parliamentary regimes they help enforce a dominant ideology and protect the ruling classes. Often political police forces were established or expanded at moments of 
crisis and once the crisis disappeared other fears were raised to justify their existence. This was the case in the USA where the FBI developed a political mission in 1917 to keep tabs on the activities of radicals who had opposed US entry into the war and where the size of the German immigrant population caused concern. At the end of the first global conflict a rise in left-wing radicalism, owing to the influence of Russia, as a reaction to war-time repression and the growth of a strengthened more militant trade union movement seeking through strikes to improve wages and conditions at a time of raging inflation, was at the base of the maintenance of the force (Theoharis in Mazower). In representative regimes political policing is justified as the means to protect a democratically elected government from those who wish to impose a minority rule through force (Berlière in Mazower). It is also sometimes claimed that by gathering information about public opinion political policing allows governments to be aware of popular demands and that this function helps moderate these governments. In democracies such a procedure seems unnecessary given that other sources of information (newspaper, elections, opinion polls, letters to members of parliament etc) serve a similar purpose. In dictatorships this function may apply but once the message being sent up from below is that the government is deeply unpopular the effect may be the very reverse of stimulating moderation. By increasing the government's feeling of isolation, by making leaders feel they have nothing to lose it can encourage rulers to lash out through harsh repression against a public which needs to be saved from itself.

Fenians, suffragettes, socialists, vagabonds, nationalists, prostitutes, drug-dealers, Jews, foreigners, terrorists, homosexuals, anarchists, spies, free-masons, fascists, paedophiles, communists, religious sects: the list of those labelled as marginals or extremists and targeted as potential threats to society by various regimes is impressive. Although most of the focus in these texts is on the repression of the extreme-left, political policing also affected right-wing targets, as in 19th century France (Berlière in Mazower). Moreover once in power communists showed no reluctance to use the police themselves as the case of the Stasi in the former GDR demonstrates (Reinke in Mazower). The activity of extremist categories could be used to justify political police activity or as a means of rallying support behind the political regime. Thus in Greece the communist bogey was used for just that end (Mazower in Mazower). The role of scape-goat allotted to foreigners in many circumstances often denied them certain fundamental liberties accorded to natives. Usually targets were officially designated by government propaganda, sometimes in direct response to public concerns. The case of the persecution of Jews in Stalinist Russia at the end of the Second World War was an exception to this rule since at the time the Soviet Union was vaunting its efforts in saving Jews from the Nazis and was supporting the creation of Israel. Arrests and executions within this category in this particular case appeared to run counter to official policy but in fact received active support from the Kremlin (Altman in Berlière \& Peschanski). An important difference should be noted between the choice of targets in democratic and totalitarian regimes. Both repressed extremist or marginal categories but whereas in democracies these groups tended to be the sum-total of political police repression, dictatorships were more prone to ever-widening definitions of what constituted a threat. As Gellately points out new legislation in Nazi Germany allowed the arrest of just about anyone (Gellately in Berlière \& Peschanski).

Between the political policing exercised by democracies and by dictatorships, certain general characteristics serve as common denominators. It is in the political 
field that police structures tend to be the most specialised; here too that activity is shrouded in the most secrecy. Metternich was not alone in wishing to maintain a veil of mystery around activities carried out in the name of state security (Emsley in Mazower). Certain police techniques are also common to both types of government. In its mildest forms political surveillance involved the routine gathering of a vast amount of information, much of which was apparently harmless but started to acquire more sinister meaning once juxtaposed with other similarly benign information. From the infiltration of political gatherings, police forces passed to the more intimate penetration of the private world of the individual- listening to conversations, intercepting correspondence, making use of informants and agents. The secrecy surrounding police missions in this domain encouraged abuses which persisted even in democracies. In some cases the police actively encouraged 'extremist' movements for their own ends or those of their political masters. In Germany at the end of the 19 th century police encouraged anarchism as a rival to the SPD. Their contemporary French counterpart planted 'anarchist' bombs themselves or subsidised 'anarchist' papers both in order to justify their own existence and to discredit this political current (Emsley; Berlière in Mazower). In rural areas of Italy police provoked violence in order to justify the use of repression (Dunnage in Mazower). Evidence would be manufactured when it couldn't be achieved by more brutal methods. Painting the door of the interrogation room red may have held aesthetic appeal for the Wichita police force but it also served the much more functional task of masking the blood which suspects were careless enough to spill during interrogations (Monkonnen in Berlière \& Peschanski). Long periods of imprisonment could sufficiently disorientate individuals into encouraging them to make false confessions. Sometimes deliberate tactics were used to accelerate this disorientation. In the Huggins' book the author describes the increasingly sophisticated methods of imprisonment and torture employed in Brazil with the use of body-stretching, live burials, insertion of electrified brillo pads into particularly moist and sensitive parts of the body, extreme sudden changes of temperature and lighting. In this example, torture was no longer being used simply as a way of obtaining information but it was also an end in itself: a form of punishment for people who would not have the right to a trial.

Although abuses were present in both democratic and totalitarian police forces important quantitative and qualificative differences must be noted. The existence of genuine counter-weights (public opinion, parliamentary debate, relative freedom of the press and a more independent justice system) in democratic regimes serves to limit the scope of these abuses which are not as openly vaunted. In modern democratic regimes, the police are aware that their professional ethic is based around a civilised notion of policing marked by a limited use of force, subordination of the police to the law and the repression of erring individuals not groups (Lévy in Berlière $\&$ Peschanski). Abuses have to be carried out clandestinely. Severe transgressions of this professional code are most common in counter-espionage policing where state secrecy is the most extreme but this activity is on the margins of police activity. In dictatorship, abuses are at the very heart of the police system. In totalitarian regimes the police are given elite status and ever widening power with the elimination of counterweights and the criminalisation of an increasing number of categories. The prerogatives of the totalitarian police force are given absolute precedence over the rights of individuals and in the confusion which then occurs between police and justice, the latter is subordinated to the former with the police assuming powers not only of arrest but also of punishment (Gellately in Berlière \& 
Peschanski; Huggins). In totalitarian regimes the police are generally not expected to conform to civilised codes of behaviour towards 'out-groups'.

Further levels of complexity are added to the comparisons of the different contexts presented when an international dimension appears either through co-operation, occupation or colonisation of another country. Co-operation in the anti-communist struggle was one aspect of International Criminal Police Commission (ICPC) activity, a further reminder of the overlap between criminal and political policing. The obvious Nazi domination of this commission ultimately served to undermine its function as an instrument of international co-ordination of anti-communism. When occupying Western European countries in 1940 the Nazis still tried to make use of the ties established through this commission to encourage collaboration with security forces in occupied countries (Fijnaut in Mazower).

Various models of occupation are presented in the 'Pouvoirs et police' text. In the Netherlands, the Nazis opted for a direct imposition of the German model. In Belgium and France they allowed greater autonomy to native security forces whilst confronting indigenous structures with the competition of Nazi competitors. In East Germany the Soviet occupier imposed its own model but hoped to eventually to be able to delegate its functions to locals. Whatever the model, occupation posed serious dilemmas to police officers of all branches. How far should traditional cultures of obedience bend to adapt to occupiers who didn't always play by the rules? Did police officers have any responsibility in carrying out orders from above? How could patriotic reflexes be reconciled with foreign subordination? What should a police officer do when faced with the professional duty to crack down on a black market which interfered with the occupier's supply lines but upon which his countrymen depended for food and other provisions? Ironically even where they wished to rely to a large extent on local structures, occupiers often had to intervene directly as in East Germany in 1953, and increasingly in Belgium and France from 1943, because the local force was either unable or unwilling to tame the patriotic sentiments of their compatriots (Tartakowsky; Lévy; Berlière et Peschanski; Fijnaut; Delpuech in Berlière et Peschanski).

British colonial policy is discussed in chapters by Jeffery on Northern Ireland (in Mazower \& in Berlière \& Peschanski) and more generally by Killingray (in Mazower). In stark contrast to the liberal model adopted for the policing of the British mainland, the policing of British colonies revolved around a gendarmerie system. Even in the period after the Second World War when all was quiet in Northern Ireland, the definitive move towards an unarmed police force was rejected. Elsewhere in the colonies laws which had long since been abandoned in Britain continued to be enforced. This was the case of the 'master and servant' legislation which helped keep wages low in the interest of the colonial state. Within this framework, the political aspect of the police role was only too evident. Not only were the police used to curb labour unrest and demands for higher wages but they also assured white supremacy, in many cases reserving a status of second class citizen to locals. With the wind of decolonisation blowing in the 1940's and 1950's, Imperial administrators faced a whole host of actual or imagined threats. Not all were directly linked to decolonisation. Trying to preserve a 'pax Britannica' meant dealing with the difficulties emerging from more general political unrest, economic and social change, urbanisation, growth and increased mobility of the population. But undoubtedly there was an anti-colonial agenda as well and just as the British had faced guerrilla warfare in Ireland in 1918-1920, similar situations faced them in Malaya in 1948 
and Kenya between 1952 and 1960 . Their response was brutal and paramilitary providing further flashpoints for greater hostility. Increasing the size of colonial police forces and giving greater emphasis to intelligence gathering could not stem the tide. In most cases the police remained loyal to the Empire but were inadequate for the circumstances which were undermining the economic viability of the colonies and Britain's reputation.

In recent years colonisation has taken a much more subtle but equally invidious form. This is the clear signal sent by Martha Huggins' book tracing the interconnection between the United States and political police forces in South America. It is not necessary for a country to occupy another to be able to exploit its potential: a much easier and cheaper way is to make use of influence gained over its police force through police training programs. In the first third of the 20th century the US was far from alone in trying to gain control over police forces in Latin America: fascist Italy was reorganising the Bolivian police and training police personnel in Venezuela and Peru, whilst France and Germany also attempted to exert their influence in the region. US attempts at that point in time consisted of establishing police constabularies, organising the dismantling of pre-existing forces and their replacement with American sponsored ones, as in Cuba or Haiti. The aim of these constabularies was to protect the western hemisphere against communist organisers and fascist espionage but they also succeeded in irritating much of the local population. The US marines sent to control the constabularies came into conflict with native opinion, since many of them brought with them a solid racial prejudice born of their origin in the southern states, few spoke local languages, their presence provoked an increase in out-of-wedlock births and their use of forced labour did little to endear them. But it was in the wake of World War Two that the US police role in these areas took on a much more dominant role and a less overt form. Truman, Eisenhower and particularly John F Kennedy considerably expanded its scope and the policy came to occupy a vital place in US foreign policy as it was less visible, cheaper and appeared more benign than direct military intervention. The stated objectives of US 'assistance' in the organisation of Latin American police was to help democratise foreign police forces and make them less brutal and corrupt. Huggins' interest in the topic evolved from the observation that US involvement had often achieved the exact opposite of its explicit goals: during the 1960's and 1970's when the policy was at its zenith, Latin American countries were marked by an increase in state-led brutality and inhumanity. From this observation Huggins concludes that a hidden agenda was in operation; the US was not trying to democratise the process of policing in its Southern neighbours but rather simply to assure its own security and spread its own anti-communist message. In offering seemingly benign assistance to these police structures, Washington sought to place foreign police in the first line of its anti-communist strategy. In some cases US help in police training was initially requested by indigenous officials in search of greater efficiency through the modernisation and professionalisation of their security forces in order to crush labour unrest or to alter the balance of power between national and local administrations. However, in most cases it was the US that initiated discussions making internal security assistance part of a wider aid package, which might also include technical help for agriculture and health.

US training programmes became the favoured technique for penetrating police structures and often began with modest help in traffic control techniques and technologies before building up into a much more large-scale operation of manipulation through training. More than $\$ 337$ million was spent by US governments in 
police assistance to third world countries in the years 1962 through to 1974. During those years almost 1 million foreign police officers received US sponsored instruction in their own countries whilst more than 5000 trained at the International Police Academy (IPA) in Washington. Here training included surveillance techniques; intelligence gathering; interrogation procedures; methods of conducting raids and crowd control procedure. Films such as Gillo Pontecorvo's 'Battle of Algiers', which showed French policemen using violent methods in 'anti-terrorist' procedures, were an integral part of the training programme. The anti-communist tilt of the training was shown clearly through exercises such as 'operation San Martin' where participants were taught how to protect a fictitious country against 'Maoland' insurgents. Significantly the end of course essays written by those completing IPA training programmes claimed the teaching had actually encouraged them in the use of physical coercion and torture.

US responsibility in the way repressive policing spiralled out of all control in Latin America was not, claims Huggins, limited to the training programmes. In its most passive form it involved simply turning a blind-eye or failing to denounce police abuses in assisted countries. More active forms of responsibility were manifold. Initial reticence within the US over providing certain sorts of equipment not traditionally associated with policing, (eg machine-guns and mortars), was shortlived. Some of the most gruesome torture in Brazil involved the combination of local ingenuity and US supplied technology. American advisors also actively encouraged certain violations of fundamental human rights- in 1963 they pressurised the Venezuelan government into the disregarding of national laws requiring the arrest and imprisonment of policemen who killed suspects, arguing instead that policemen who killed terrorists should be immediately restored to duty. Despite its claim to be furthering democracy, the US was the main perpetrator in the overthrow of certain democratic governments. In Guatemala, the US orchestrated the overthrow of the democratically elected Jacobo Arbenz Guzman and his replacement by the brutal Castillo Armas who thereafter was praised by the US for an anti-communism which included murders and torture. Similarly in Chile, the US was active in the overthrow of Allende and his replacement by Pinochet- hence their opposition to the recent extradition proceedings concerning the former dictator as he was called to account for the brutality of his government.

At a time when the crimes perpetrated by communist regimes are coming increasingly under the historical spotlight ${ }^{3}$ these books add to that debate (in particular Altman in Berlière/Peschanski) but also serve as a solid reminder that crimes committed in the name of anti-communism should not be forgotten. Ultimately these books all underline just how far police and politics are intimately linked. Huggins claims that «all policing is political, ranging on a continuum from police being very visible handmaids of organised power, as historically in much of Latin America, to their relationship to power being obscured by the ideologies of democracy and social control that claim to make police merely extensions of a class-neutral state and the 'people'».

Simon Kitson

University of Birmingham, U.K.

S.K.Kitson@bham.ac.uk 